\title{
Analisis Kelayakan Usaha Produksi Ayam Pedaging Berbasis Pangan Lokal dengan Variasi pada Kalsium dan Fosfor
}

\author{
Dira Asri Pramita ${ }^{\mathrm{a}}$, Charles Venirius Lisnahan ${ }^{\mathrm{b}}$, Alfred Nubatonis ${ }^{\mathrm{c}}$ \\ ${ }^{a}$ Fakultas Pertanian, Universitas Timor, Kefamenanu, TTU - NTT, Indonesia.Email: diraap.dap@ gmail.com \\ ${ }^{b}$ Fakultas Pertanian, Universitas Timor, Kefamenanu, TTU - NTT, Indonesia Email: charleslisnahan@yahoo.co.id \\ ${ }^{c}$ Fakultas Pertanian, Universitas Timor, Kefamenanu, TTU - NTT, Indonesia Email: nubatonisalfred@gmail.com
}

\section{Article Info}

\section{Article history:}

Received 20 Juli 2020

Received in revised form 13 Agustus 2020

Accepted 2 September 2020

DOI:

https://doi.org/10.32938/ag.v5i4.116

Keywords:

Fosfor

Kalsium

Layak Ekonom

Pakan Lokal

\section{Abstrak}

Penelitian ini bertujuan mengetahui kelayakan usaha produksi ayam pedaging berbasis pangan lokal dengan variasi pada kalsium dan fosfor; dan mengetahui perbedaan kelayakan usaha yang diperolehnya. Penelitian ini dilaksanakan di Kandang peternak Kelurahan Sasi, Kefamenanu selama 2 bulan (Juli-Agustus, 2020). Sebanyak 96 ekor day old chick (DOC) ayam broiler digunakan dalam penelitian ini. Penelitian dilakukan dengan metode eksperimen menggunakan Rancangan Acak Lengkap terdiri dari 4 perlakuan dan 4 ulangan. Masing masing ulangan terdiri dari 6 ekor ayam broiler umur 1 hari. Parameter yang diamati adalah berat badan, efisiensi biaya pakan, harga penjualan, dan kelayakan usaha. Data berat badan, biaya pakan dan harga penjualan ayam dianalisis dengan Analisis Varians (Anova) dan uji Duncan, sedangkan kelayakan usaha dianalisis dengan rasio B/C. Hasil penelitian menunjukkan bahwa berat badan, biaya pakan dan harga penjualan ayam pedaging tertinggi terdapat pada $P_{3}$. Terdapat efisiensi biaya pakan pada $P_{3}$ dan $P_{2}$ dibandingkan dengan $P_{1}$ dan $P_{0}$ $(\mathrm{P}<0,05)$, dan penerimaan tertinggi pada $\mathrm{P} 3$. Perlakuan dengan suplementasi $2,0 \%$ kalsium dan $0,5 \%$ fosfor $\left(\mathrm{P}_{3}\right)$ menjadi perlakuan dengan kelayakan ekonomi paling tinggi. Selain itu, variasi perlakuan secara ekonomi memberikan perbedaan yang signifikan dari segi biaya dan nilai jual ayam per ekor. Disimpulkan bahwa penggunaan pakan lokal jagung kuning dan bekatul dengan suplementasi mineral kalsium dan fosfor dapat menekan biaya produksi ayam broiler.

\section{Pendahuluan}

Ayam broiler berperan dalam ketahanan pangan untuk kebutuhan masyarakat. Siklus produksi ayam broiler yang pendek dan efisiensi pakan yang tinggi karena pertumbuhan yang cepat perlu didukung oleh manajemen pakan yang baik. Tujuan dari usaha produksi ayam broiler adalah mendapat keuntungan yang layak. Untuk itu semua faktor produksi harus diperhatikan sepert manajemen pakan. Selama ini pakan yang digunakan adalah pakan kompli (komersial) yang bagi beternak cukup mahal sehingga peternak sering mendapa keuntungan yang rendah dari usaha tersebut. Beberapa bahan pakan diimpor dari luar negeri yang sudah tentu hargannya mahal misalnya tepung ikan, bungki kedelei dan juga sebagian jagung kuning. Hal ini karena produksi dalam negeri tidak tercukupi.

Salah satu alternatif dalam mengatasi permasalahan ini yaitu dengan memanfaatkan pakal lokal. Untuk itu penting dimanfaatkan pakan lokal yang memenuhi kriteria untuk memacu pertumbuhan ayam broiler tersebut Penggunaan pakan lokal bertujuan menekan biaya produksi karena lebih murah dan mudah diperoleh. Praktik penggunaan pakan local tetap diperhartikan kualitas pakannya dan kebutuhan ternak ayam seperti protein dan energi. Pakan sumber energy seperti jagung dan bekatul merupakan pakan utama unggas. $\mathrm{Ha}$ ini karena energi yang terkandung dalam pakan tersebut cukup tinggi. Akan tetapi kedua bahan pakan tersebut kandungan mineral terutama kalsium dan fosfor rendah dan juga banyak mengandung fitat yang dapat mempengaruhi pencernaan dan penyerapan kedua mineral tersebut (Wulandari et al., 2012).

Kalsium dan fosfor merupakan makronutrien yang dibutuhkan ayam untuk pertumbuhan tulang (Han et al., 2016; Abdulla et al., 2017). Sekitar 70\% tulang ayam mengandung kalsium dan fosfor. Wilkinson et al. (2011) dan Xue et al. (2016) menyatakan bahwa mineral kalsium dan posfor merupakan dua mineral yang dibutuhkan untuk pertumbuhan tulang dan produksi telur metabolism karbohidrat dan lemak. Salah satu upaya intensifikasi pemanfaatan pakan lokal perlu dimodifikasi dengan variasi makro maupun micronutrien seperti kalsium dan fosfor.

Selain kecukupan nutrien, pemanfaatan pakan lokal dengan variasi kalsium dan fosfor juga harus unggul dari sisi ekonomi. Penggunaan pakan loka diharapkan mampu menekan biaya pakan yang tinggi dalam produksi ayam pedaging. Selanjutnya, penggunaan pakan ini mampu memberikan keuntungan ekonomi yang layak bagi peternak. Salah satu indikator dalam penilaian kelayakan usaha yaitu dengan melihat rasio penerimaan, keuntungan dan biaya. Untuk itu, dalam penelitian akan dikaji kelayakan usaha ayam pedaging berbasis pakan lokal dengan variasi kalsium dan fosfor. Tujuan penelitian ini adalah mengetahui kelayakan usaha produksi ayam pedaging berbasis pangan lokal dengan variasi pada kalsium dan fosfor; dan mengetahui perbedaan kelayakan usaha yang diperolehnya.

\section{Metode}

Penelitian ini dilakukan di Kelurahan Sasi, Kefamenanu selama 2 bulan dari bulan Juli sampai Agustus 2020. Penelitian ini menggunakan 96 ekor DOC ayam broiler strain CP 707. Pakan yang diberikan adalah pakan control terdiri dari jagung kuning, bekatul, tepung ikan, bungkil kedelei, asam amino methionine, lysine, threonine, premix vitamin, kalsium dan fosfor. Pemberian pakan dan air minum secara adlibitum Kandang yang digunakan adalah kandang litter berukuran $1 \mathrm{~m} \mathrm{X} 1 \mathrm{~m} \mathrm{X} 70 \mathrm{~cm}$ sebanyak 16 petak. Peralatan yang digunakan adalah tempat pakan, tempat minum, timbangan, thermometer, lampu pijar dan peralatan kebersihan kandang.

Penelitian ini menggunakan rancangan acak lengkap (RAL) dengan 4 perlakuan dan 4 ulangan, masing-masing ulangan terdiri dari 6 ekor anak ayam. Perlakuan yang diberikan yaitu $\mathrm{P}_{0}$ (pakan kontrol tanpa suplementasi kalsium dan fosfor); $\mathrm{P}_{1}$ (suplementasi $1,0 \%$ kalsium dan $0,5 \%$ fosfor; $\mathrm{P}_{2}$ (suplementasi $1,5 \%$ kalsium dan $0,5 \%$ fosfor) dan $\mathrm{P}_{3}$ (suplementasi $2,0 \%$ kalsium dan $0,5 \%$ fosfor).

Variabel yang diamati meliputi berat badan akhir dan biaya pakan. Setelah itu menghitung penerimaan dari usaha produksi yaitu harga dikalikan dengan berat badan ayam untuk setiap perlakuan. Data dianalisis menggunakan Analisi Varians dan Uji Duncan dan dilanjutkan dengan analisis ekonomi meliputi analisis $\mathrm{B} / \mathrm{C}$ rasio yang hitung per ekor dengan rumus sebagai berikut:

$$
\mathrm{B} / \mathrm{C}=\frac{B_{i}}{T C_{i}}
$$

Di mana, $R_{i}=P \times Q_{i} ; T C_{i}=F C+V C_{i}$

Keterangan:

$$
\begin{array}{ll}
\mathrm{i} & =\text { Perlakuan ke } 0,1,2, \text { dan } 3 \\
\mathrm{R} & =\text { Penerimaan } \\
\mathrm{P} & =\text { Harga } \\
\mathrm{Q} & =\text { Berat bedan akhir } \\
\mathrm{TC} & =\text { Total biaya } \\
\mathrm{FC} & =\text { Total biaya tetap } \\
\mathrm{VC} & =\text { Total biaya variabel perlakuan ke } \mathrm{i} \\
\mathrm{B} & =\text { Keuntungan }(\mathrm{R}-\mathrm{TC}) .
\end{array}
$$

Pengambilan keputusan dari analisis ini yaitu B/C lebih besar (>) dari 1 maka usaha produksi ayam pedaging menurut perlakuan ke i layak secara ekonomi. Sebaliknya jika nilai B/C lebih kecil $(<)$ dari 1 maka usaha produksi ayam pedaging menurut perlakuan ke i tidak layak secara ekonomi. Selanjutnya dilakukan uji beda antar perlakuan untuk memastikan ada atau tidak perbedaan yang signifikan dari penerimaan dengan analysis of variance (ANOVA). Mode analysis of variance dapat dilihat sebagai berikut:

\section{$F_{\text {hit }}=\frac{\text { kuadrat antar kelompok (SSB) }}{\text { kuadrat dalam kelompok (SSW) }}$}

Kriteria pengambilan keputusan dalam pengujian yaitu apabila probabiltas F-hitung lebih kecil $(<)$ dari alfa 5 persen $(0,05)$ maka terdapat perbedaan biaya dan nilai jual yang signifikan dari produksi ayam pedaging antar perlakuan dan sebaliknya.

\section{Hasil dan Pembahasan}

\subsection{Produksi ayam broiler berdasarkan perlakuan}

Produksi ayam pedaging dilihat dari berat badan akhirnya. Berat badan ayam broiler berdasarkan analisis statistik menunjukkan perbedaan yang signifikan $(\mathrm{P}<0,05)$. Perbedaan berat badan ayam pedaging masing-masing $\mathrm{P}_{0}$ $\mathrm{P}_{1}, \mathrm{P}_{2}$ dan $\mathrm{P}_{3}$ terlihat pada Gambar 1

Suplementasi $1,0 \%$ kalsium dan $0,5 \%$ fosfor dalam pakan $\left(\mathrm{P}_{1}\right)$ meningkatkan berat badan $6,88 \%$ dibandingkan dengan $\mathrm{P}_{0}$. Apabila level kalsium dinaikan menjadi $1,5 \%\left(\mathrm{P}_{2}\right)$, berat badan tidak signifikan dibandingkan dengan $\mathrm{P}_{1}$. Berat badan meningkat pada level $2,0 \%\left(\mathrm{P}_{3}\right)$ sebesar 5,06\% dibandingkan dengan $\mathrm{P}_{2}$ (Tabel 1)

Suplementasi kalsium-fosfor dengan rasio berbeda mempengaruhi berat badan ayam pedaging. Semakin tinggi level kalsium pakan, semakin meningka barat badan. Kalsium dan fosfor mempengaruhi metabolisme tubuh ayam. Han et al. (2016) menyatakan bahwa kalsium berperan dalam aktifator beberapa enzim seperti enzim lipase pankreatik, asam phosphatase, cholinesterase dan suksinink dehydrogenase. Sebagai aktifator enzim, kalsium menstimulir kontraksi otot dalam mengatur transmisi impuls dari satu sel ke sel yang lainnya 
melalui pengontrolan produksi acetyl choline (Hamdi et al., 2015). Selain itu kalsium berperan dalam absorbs vitamin $\mathrm{B}_{12}$ dan menjaga integritas membran sel dan jaringan skeletal (Abdulla et al., 2017). Talpur et al. (2012) menyatakan bahwa kekurangan kalsium pada ayam akan menyebabkan pertumbuhan terhambat, efisiensi pakan menurun dan mineralisasi pada tulang rendah. Pencernaan dan penyerapan kalsium dan fosfor dipengaruhi oleh antinutrien dalam bahan pakan terutama fitat yang mengikat fosfor (Zeller et al., 2015).

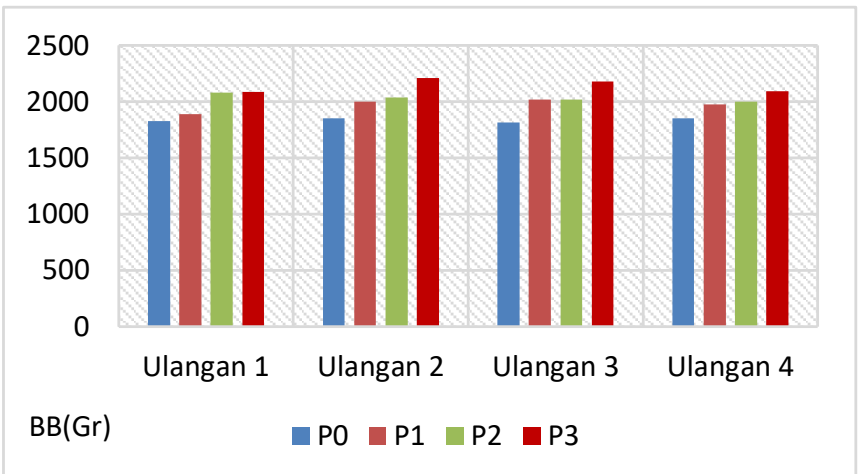

Gambar 1. Rata-rata berat badan ayam pedaging (g/ekor)

$\underline{\text { Tabel 1. Deskriptif berat badan ayam berdasarkan perlakuan }}$

\begin{tabular}{lcccc}
\hline \multirow{2}{*}{ Ukuran statistik } & \multicolumn{4}{c}{ Perlakuan } \\
\cline { 2 - 5 } & $\mathrm{P}_{0}$ & $\mathrm{P}_{1}$ & $\mathrm{P}_{2}$ & $\mathrm{P}_{3}$ \\
\hline Rata-rata (g) & 1837,00 & 1972,75 & 2034,75 & 2143,25 \\
Simpangan baku & 18,49 & 57,89 & 35,38 & 61,84 \\
Koefisien variasi (\%) & 1,01 & 2,93 & 1,74 & 2,88 \\
\hline
\end{tabular}

\subsection{Biaya pakan ayam}

Penggunaan biaya pakan dalam penelitian dihitung berdasarkan jumlah bibit. Biaya produksi selain pakan menunjukan nilai yang sama yaitu sebesar Rp.34,947.91/ekor sedangkan untuk pakan, mengikuti variasi perlakuan yang diberikan Lebih jelasnya terlihat pada Tabel 2 .

Tabel 2. Deskriptif biaya pakan berdasarkan perlakuan

\begin{tabular}{lcccc}
\hline \multirow{2}{*}{ Ukuran statistik } & $\mathrm{P}_{0}$ & $\mathrm{P}_{1}$ & $\mathrm{P}_{2}$ & $\mathrm{P}_{3}$ \\
\cline { 2 - 5 } & 15131.13 & 15368.35 & 15449.09 & 15576.57 \\
Rata-rata (Rp/ekor) & 247.58 & 144.6 & 208.27 & 50.14 \\
Simpangan baku & 1.63 & 0.94 & 1.34 & 0.32 \\
Koefisien variasi (\%) & & &
\end{tabular}

Hasil pada Tabel 2 menunjukan biaya pakan terbesar berada pada perlakuan pertama (P0) sedangkan tertinggi berada pada perlakuan keempat (P3). Nilai koefisien variasi menunjukan bahwa biaya pakan dengan keragaman terbesar yaitu pada perlakuan pertama (P0) sedangkan biaya pakan dengan keragaman terkecil atau konstan yaitu perlakuan ke empat (P3). Variasi yang ditimbulkan ini menunjukan adanya penggunaan jumlah pakan yang cukup berbeda dari ulangan pertama sampai ulangan keempat yaitu pada perlakuan pertama (P0).

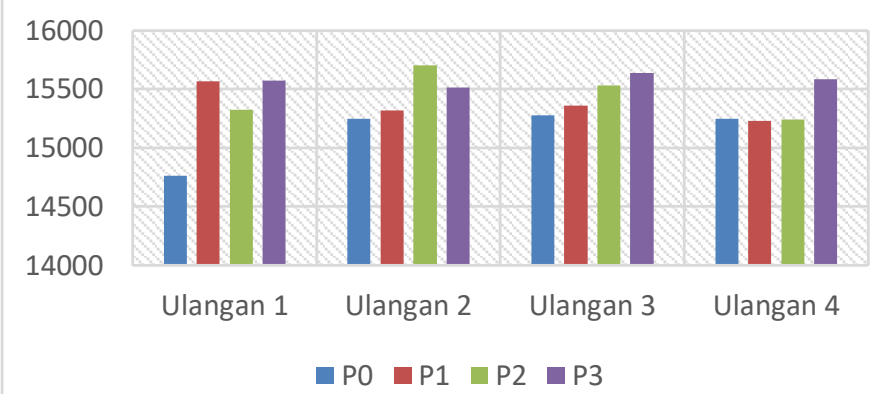

Gambar 2. Rata-rata biaya pakan (Rp/ekor).

Variasi biaya pakan pada gambar diatas terkait suplementasi kalsiumfosfor yang berbeda. Pada perlakuan pertama (P0) rata-rata biaya pakan cenderung meningkat dari ulangan pertama sampai ulangan keempat sedangkan perlakuan kedua (P1), biaya pakan per ekor cenderung berfluktuatif. Selanjutnya, pada perlakuan ketiga (P2), biaya pakan cenderung menurun yang terlihat pada ulangan kedua sampai ulangan terakhir sedangkan perlakuan keempat (P3) biaya pakan per ekor cenderung berfluktuatif dengan pergerakan yang konstan.

\subsection{Nilai jual dan keuntungan menurut perlakuan}

Nilai jual ayam dalam penelitian ini dilihat dalam bentuk karkas bersih yaitu satuan kilogram. Harga jual per kilogram karkas sebesar Rp. 45,000. Berdasarkan harga tersebut maka didapatlah nilai penjualan dari setiap unit penelitiannya pada Tabel 3 .

Tabel 3. Deskriptif keuntungan berdasarkan perlakuan.

\begin{tabular}{lcccc}
\hline \multirow{2}{*}{ Ukuran statistik } & \multicolumn{4}{c}{ Perlakuan } \\
\cline { 2 - 5 } & $\mathrm{P}_{0}$ & $\mathrm{P}_{1}$ & $\mathrm{P}_{2}$ & $\mathrm{P}_{3}$ \\
\hline Rata-rata (Rp/ekor) & 32585.95 & 38457.48 & 41166.74 & 45921.76 \\
Simpangan baku & 832.19 & 2605.17 & 1591.99 & 2782.82 \\
Koefisien variasi (\%) & 2.553 & 6.774 & 3.867 & 6.059 \\
\hline
\end{tabular}

Hasil pada Tabel 3 menunjukan keuntungan terbesar dari pengusahaan ayam pedaging berbasis pangan local dari variasi kalsium dan fosfor berada pada perlakuan keempat (P3) selanjutnya yaitu pada perlakuan ketiga (P2). Lebih lanjut, jika dicermati nilai dari kedua perlakuan ini menunjukan bahwa variasi keuntungan dari beberapa ulangan terbesar berada pada perlakuan keempat (P3) sedangkan terendah yaitu perlakuan ketiga (P2). Hasil ini menujukan adanya konsep high risk high return artinya semakin besar risiko yang dihadapi maka semakin besar keuntungan yang diperoleh dari usaha produksi ayam pedaging ini.

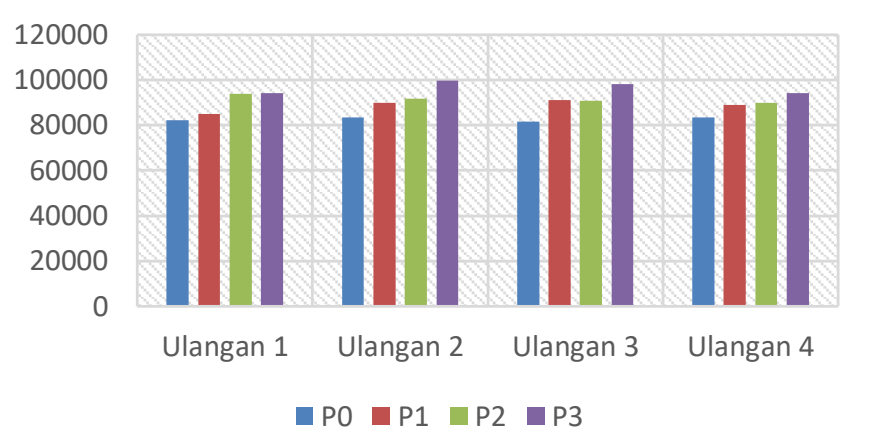

Gambar 3. Rata-rata nilai jual ayam (Rp/ekor)

Hasil pada Tabel 3 menunjukan bahwa nilai jual ayam dipengaruhi oleh berat karkas yaitu semakin tinggi berat karkas maka nilai penjualan akan semakin tinggi. Sebagaimana pendapat Soeparno (1992), yaitu berat karkas ayam dipengaruhi oleh konsumsi ransum, umur, berat hidup dan berbagai faktor lainnya. Lebih lanjut, untuk kentungan per ekor terlihat pada Gambar 4.

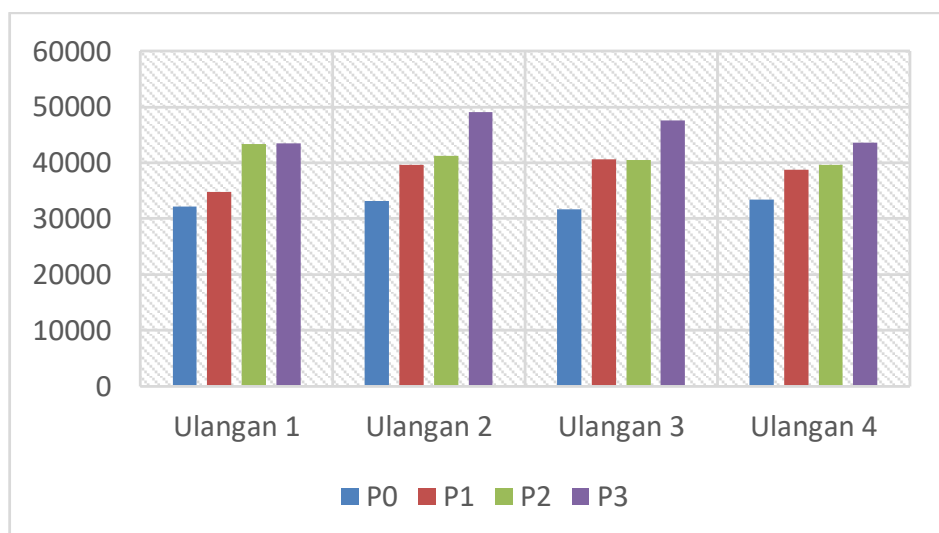

Gambar 4. Rata-rata keuntungan produksi ayam (Rp/ekor).

Hasil pada Gambar 4 menunjukan bahwa untuk semua perlakuan dan ulangan yang dilakukan memberikan keuntungan dari produksi ayam. Nilai ini terlihat dari keuntungan atau nilai yang bertanda positif. Namun, jika dilihat lagi dari keempat perlakuan, perlakuan keempat (P3) memberikan keuntungan tertinggi untuk setiap ekornya. Meskipun perlakuan ini (P3) memberikan biaya yang terbesar namun berat badan yang dihasilkan juga lebih baik dibandingkan perlakuan lainnya. Mengenai hasil ini, Harahap (2005) menjelaskan bahwa keuntungan menjadi indikator yang penting dalam usaha. Hal ini dikarenakan keuntungan menjadi dasar dalam perhitungan pajak, kebijakan investasi dan pengambilan keputusan, peramalan keuntungan dimasa yang akan datang dan yang terpenting dasar dalam penilaian prestasi atau kinerja perusahaan.

\subsection{Kelayakan usaha produksi ayam berdasarkan perlakuan}

Analisis kelayakan usaha terlihat dari nilai R/C dan B/C ratio. Jika lebih dari 1 maka usaha produksi ayam layak dijalankan. Hasil analisis dapat dilihat pada Tabel 4. 
Tabel 4. Analisis kelayakan usaha berdasarkan perlakuan

\begin{tabular}{lrrrr}
\hline \multirow{2}{*}{ Variabel } & \multicolumn{5}{c}{ Perlakuan } \\
\cline { 2 - 5 } & \multicolumn{1}{c}{$\mathrm{P}_{0}$} & \multicolumn{1}{c}{$\mathrm{P}_{1}$} & \multicolumn{1}{c}{$\mathrm{P}_{2}$} & \multicolumn{1}{c}{$\mathrm{P}_{3}$} \\
\hline Biaya (Rp/ekor) & $50,079.04$ & $50,316.26$ & $50,397.00$ & $50,524.49$ \\
Penerimaan (Rp/ekor) & $82,665.00$ & $88,773.75$ & $91,563.75$ & $96,446.25$ \\
Keuntungan (Rp/ekor) & $32,585.96$ & $38,457.48$ & $41,166.74$ & $45,921.76$ \\
B/C & 0.65 & 0.76 & 0.82 & 0.91 \\
\hline
\end{tabular}

Sumber: Analisis data primer (2020).

Hasil uji kelayakan menunjukan bahwa secara keseluruhan keempat (4) perlakuan memberikan nilai B/C yang berada di bawah 1 . Artinya biaya yang dikeluarkan belum memberikan manfaat yang lebih besar (nilai jual). Namun, jika dilihat perlakuan ke empat $\left(\mathrm{P}_{3}\right)$ menjadi usaha produksi ayam dengan tingkat kelayakan usaha tertinggi dibandingkan tiga (3) perlakuan lainnya. Perlakuan pertama $\left(\mathrm{P}_{0}\right)$ mempunyai biaya produksi terendah namun tingkat penerimaannya yang rendah juga. Sebaliknya, perlakuan ke empat $\left(\mathrm{P}_{3}\right)$ mempunyai penerimaan yang tertinggi meskipun diikuti dengan biaya per ekornya yang tinggi pula.

\subsection{Uji perbedaan biaya dan nilai jual produksi menurut perlakuan}

Pengujian perbedaan dengan Anova dilakukan untuk memastikan secara statistik terdapat perbedaan biaya dan nilai jual yang signifikan dari setiap perlakuan. Hasil pengujian dapat dilihat pada Tabel 5.

Tabel 5. Hasil pengujian ANOVA pada biaya dan nilai jual per ekor.

\begin{tabular}{lcc}
\hline Variabel & F test & Probabilitas \\
\hline Biaya produksi & 4.391 & 0.026 \\
Nilai jual ayam & 29.806 & 0.000 \\
\hline Sumber: Analisis data primer (2020) & &
\end{tabular}

Sumber: Analisis data primer (2020)

Pengujian analysis of variance (ANOVA) menunjukan nilai yang signifikan baik pada variabel biaya produksi dan nilai jual ayam. Hasil uji ini mengkonfirmasi bahwa ada perbedaan yang jelas dari biaya yang dikeluarkan dan nilai yang jual yang diterima dari setiap perlakuan.

\section{Simpulan}

Berdasarkan hasil dan pembahasan dapat disimpulkan sebagai berikut: Produksi ayam pedaging dengan perlakuan suplementasi $2,0 \%$ kalsium dan $0,5 \%$ fosfor $\left(\mathrm{P}_{3}\right)$ memberikan tingkat kelayakan ekonomi paling tinggi dibanding perlakuan lainnya. Perlakuan berbasis pakan lokal dengan variasi pada kalsium dan fosfor pada produksi ayam pedaging memberikan perbedaan yang signifikan dari segi biaya dan nilai jual per ekor.

\section{Pustaka}

Abdulla, N.R., T.C. Loh, H. Akit, A.Q. Sazili, H. L. Foo, K.Y. Kareem, R. Mohmad and R.A. Rahim. 2017. Effects of dietary oil sources, calcium and phosphorus levels on growth performance, carcass characteristics and bone quality of broiler chickens. Journal of Applied Animal Research. 45(1): 423-429

Han, J., J. Wang, G. Chen, H. Qu, J. Zhang, C. Shi, Y. Yan, and Y. Cheng. 2016. Effects of calcium to non-phytate phosphorus ratio and different sources of vitamin $\mathrm{D}$ on growth performance and bone mineralization in broiler chickens. Revista Brasileira de Zootecnia. 45(1): 1-7.

Hamdi, M., S. L'opez-Verg'e, E.G. Manzanilla, A.C. Barroeta, and J.F. P'erez. 2015. Effect of different levels of calcium and phosphorus and their interaction on the performance of young broilers. Poultry Science. 94: 2144-2151.

Harahap. 2005. Teori Akuntansi. PT. Raja Grafindo Persada, Jakarta.

Huber, K., E. Zeller, and M. Rodehutscord. 2015. Modulation of small intestinal phosphate transporter by dietary supplements of mineral phosphorus and phytase in broilers. Poultry Science. 94: 1009-1017.

Pakage S, Hartono B, Fanani Z, Nugroho BA. 2014. Analysis of Technical Efficiency of Poultry Broiler Business with Pattern Closed House System in Malang East Java Indonesia. Journal of Economics and Sustainable Development. 5(12): 16-22.

Soeparno. 1992. Teknologi Pengawasan Daging. Institute Pertanian Bogor.

Talpur, M.Z., M.I. Rind, A. Memon, F.N. Shar and N.A. Ujjan. 2012. Effect of Dietary Calcium on the Performance of Commercial Chicken. J. Vet. Anim. Sci. 2: 101-106.

Wilkinson, S.J., P.H. Selle, M.R. Bedford and A.J. Cowieson. 2011. Exploiting calcium-specific appetide in poultry nutrition. World's Poultry Science Journal. 67: 21-30.

Wulandari, E.C., W Murningsih and H.I. Wahyuni. 2012. Deposition of Calsium and Phosphorous to Egg Shells of Arab Hens Fed Various Levels of Azolla Microphylla. Animal Agriculture Journal. 1(1): 507-520.

Xue, P.C., K.M. Ajuwon, and O. Adeola. 2016. Phosphorus and nitrogen utilization responses of broiler chickens to dietary crude protein and phosphorus levels. Poultry Science 95: 2615-2623.

Zeller, E., M. Schollenberger, M. Witzig, Y. Shastak, I. K'uhn, Ludwig, E Hoelzle and M. Rodehutscord. 2015. Interactions between supplemented mineral phosphorus and phytase on phytate hydrolysis and inositol phosphates in the small intestine of broilers. Poultry Science. 94: 10181029. 